\title{
The Influence of Social Media, Product Quality, and Price on Purchasing Decisions on UMKM Ayra \& Eve in Surabaya
}

\author{
Weni Widiasti Ningrum ${ }^{1}$, I Nyoman Sudapet ${ }^{2}$, Hamzah Denny Subagio ${ }^{3}$ \\ Universitas Narotama Indonesia \\ weniwidasti@gmail.com
}

\begin{abstract}
Purchasing decisions are very important. Because a product will be sold, with a purchase decision made by consumers. As with the UMKM Ayra \& Eve in Surabaya, the more purchasing decisions made by consumers, the more products are sold. In this study to analyze the influence of social media, product quality, price on purchasing decisions. This study uses quantitative research with a sample of 80 respondents. And data were analyzed using multiple linear regression analysis techniques and classical assumption tests. Simultaneous social media, product quality, and significant price for purchasing decisions. Therefore, the UMKM Ayra\&Eve in Surabaya must be maintained.
\end{abstract}

Keywords: social media, product quality, price, purchasing decisions

\section{INTRODUCTION}

As the development of an increasingly modern era, the need for gifts or gifts both for weddings, birthdays, graduations or other events is increasing. Therefore, increasing online marketing also markets various gift products through social media with various forms or models for various needs or events. It is easy for consumers to find various gift sellers through social media like Instagram, so that at an affordable cost and without visiting directly to meet the seller, their needs for various prizes have been fulfilled. This creates its own competition for sellers through social media to influence buyers' buying decisions.

In influencing purchasing decisions, a good and good marketing strategy is needed. One way is to do online marketing using social media which is popular in this modern age. Online marketing is the marketing of a product from the seller to the consumer by using electronic media making it easier for consumers to meet their needs without having to directly visit the store or seller. Like through social media Instagram and others. In addition, by providing good quality products and prices, consumer purchasing decisions also increase. Like the UMKM Ayra\&Eve in Surabaya, which is one of the UMKM Ayra\&Eve with online marketing that sells various gift products for events. Where has quite a lot of competitors. Therefore it must improve social media as a marketing tool and maintain product quality, as well as good prices.

Social media according to Kotler, Phillip \& Keller, (2012) social media is a suggestion for consumers to share text, images, audio and video information with each other and with companies and vice versa. Kotler, (2005:49) states that product quality is the overall characteristics and of a product or service on the ability to satisfy expressed / implied needs. While according to Simamora, (2003:574) Price is the amount of money charged or imposed on a product or service .

\section{LITERATURE REVIEW}

\section{Marketing Management}

The Influence of Social Media, Product Quality, and Price on Purchasing Decisions on UMKM Ayra \& Eve in Surabaya

Weni Widiasti Ningrum, I Nyoman Sudapet, Hamzah Denny Subagio³ 
Marketing management is an art and science for selecting target markets and acquiring, maintaining and growing customers by creating, delivering, communicating superior customer value (Kotler, P, 2009:6)

\section{Social Media}

Social media according to Kotler, Philip \& Keller, (2012) social media is a suggestion for consumers to share text, images, audio and video information with each other and with companies and vice versa. Another definition of social media is a group of internet-based applications that are built on ideological and web 2.0 technologies, which allow creation and exchange to occur from content users.

\section{Product Quality}

Is to reflect the product's ability to carry out its duties which include durability, reliability or progress, strength, ease in packaging and product repairs (Kotler dan Armstrong, 2008:266). Product quality is that consumers will be satisfied with the results of their evaluation showing that the products they use are of high quality (Lupioadi, 2001:158).

\section{Price}

Price is the amount of money that the customer must pay to obtain the product. Price is the price paid and the ways or conditions related to the sale (Payne, 2007:28).

\section{Purchasing decision}

Schiffman dan Kanuk, (2004:547) states the purchase decision is the choice of two or more alternative choices of purchasing decisions, meaning that someone can make a decision, there must be several alternative choices. A purchase decision is a process of making a purchase decision that includes determining what will be purchased or not making a purchase and the decision is obtained from previous activities (Assauri, 2004:141)

\section{RESEARCH METHODS}

\section{Types of Research}

The type of research used by researchers is associative research with quantitative research data types.

Quantitative research methods can be interpreted as research methods based on the philosophy of positivism, used to examine certain populations or samples, sampling techniques are generally done randomly, data collection uses research instruments, quantitative / statistical data analysis with the aim of testing hypotheses that has been established.

\section{Population and Samples}

In the book Business Research Methods Sugiyono, (2008), the population is a generalization region consisting of: objects / subjects that have certain qualities and characteristics set by researchers to be studied and then conclusions drawn. The population in this study is the unknown number of UMKM Ayra\&Eve consumers in Surabaya.

The sample is part of the number and characteristics of the population. (Book of Business Research Methods).

Researchers in determining the number of samples that will be used in this study use the formula Joseph F. Hair, (2014) where the sample size depends on the number of all indicators multiplied by at least 5 to a

The Influence of Social Media, Product Quality, and Price on Purchasing Decisions on UMKM Ayra \& Eve in Surabaya

Weni Widiasti Ningrum, I Nyoman Sudapet, Hamzah Denny Subagio ${ }^{3}$ 
maximum of 10 . In this study there were 16 indicators, using the minimum respondents in this study namely 16 x $5=80$. Data collection is done by distributing questionnaires.

\section{Research Instrument}

To provide an overview of the preparation of the following research questionnaire, the design of the research instrument is presented.

Table 1. Design of Research Instruments

\begin{tabular}{|c|c|c|c|c|}
\hline \multirow{2}{*}{$\begin{array}{l}\text { Variable } \\
\text { Independent } \\
\text { Variable }\end{array}$} & \multirow[t]{2}{*}{ Operational Definition } & \multicolumn{2}{|c|}{ Indicator } & \multirow[t]{2}{*}{ Scale } \\
\hline & & & & \\
\hline \multirow[t]{3}{*}{ Social Media (X1) } & \multirow[t]{3}{*}{$\begin{array}{l}\text { Social Media is a tool used by } \\
\text { UMKMAyra\&Eve to share } \\
\text { information in the form of } \\
\text { text, images, audio, and video } \\
\text { to consumers. So that with } \\
\text { social media relations with } \\
\text { consumers can be established. }\end{array}$} & 1) & $\begin{array}{l}\text { UMKM Ayra\&Eve establish good } \\
\text { communication on social media. } \\
\text { Customers can interact well on social } \\
\text { media to find out information on } \\
\text { Ayra\& Eve products. }\end{array}$ & \multirow[t]{3}{*}{ Likert } \\
\hline & & 3) & $\begin{array}{l}\text { UMKM Ayra\&Eve still establish good } \\
\text { communication on social media post- } \\
\text { purchase, (both in providing further } \\
\text { info or bookings). }\end{array}$ & \\
\hline & & 4) & $\begin{array}{l}\text { Through social media, UMKM } \\
\text { Ayra\&Eve have delivered all product } \\
\text { information in a complete and } \\
\text { interesting manner. }\end{array}$ & \\
\hline \multirow[t]{6}{*}{$\begin{array}{l}\text { Product } \\
\text { (X2) }\end{array}$} & \multirow{6}{*}{$\begin{array}{l}\text { Product quality is the ability } \\
\text { of a product that is produced } \\
\text { by the UMKM Ayra\&Eve as } \\
\text { well as possible to produce } \\
\text { customer satisfaction. }\end{array}$} & 1) & $\begin{array}{l}\text { The quality of the material used is } \\
\text { good. }\end{array}$ & \multirow[t]{6}{*}{ Likert } \\
\hline & & 2) & $\begin{array}{l}\text { UMKM Ayra\&Eve products are } \\
\text { special in terms of uniqueness. }\end{array}$ & \\
\hline & & 3) & $\begin{array}{l}\text { UMKM Ayra\&Eveproducts are } \\
\text { available in various sizes. }\end{array}$ & \\
\hline & & 4) & $\begin{array}{l}\text { Custom products purchased in } \\
\text { accordance with order details (in terms } \\
\text { of forms or other special requests). }\end{array}$ & \\
\hline & & 5) & $\begin{array}{l}\text { The durability of UMKM Ayra\&Eve } \\
\text { products is quite durable. }\end{array}$ & \\
\hline & & 6) & $\begin{array}{l}\text { UMKM Ayra\&Eve products include } \\
\text { attractive products to buy. }\end{array}$ & \\
\hline \multirow[t]{3}{*}{ Price $(\mathrm{X3})$} & \multirow{3}{*}{$\begin{array}{l}\text { Prices have a very important } \\
\text { role to influence consumers to } \\
\text { be able to buy products } \\
\text { offered by UMKM Ayra\& } \\
\text { Eve. }\end{array}$} & 1) & 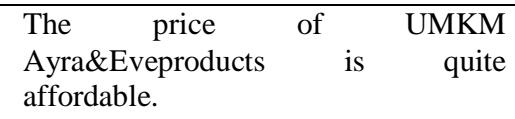 & \multirow[t]{3}{*}{ Likert } \\
\hline & & 2) & $\begin{array}{l}\text { Prices offered are in accordance with } \\
\text { the benefits \& features of the product. }\end{array}$ & \\
\hline & & 3) & $\begin{array}{l}\text { UMKM Ayra\&Evehave given } \\
\text { discounts, both at certain moments or } \\
\text { loyal customers. }\end{array}$ & \\
\hline
\end{tabular}

\section{Dependent Variable}

Purchasing Decision (Y)
Purchasing decisions are a very important element in marketing. Because without a
1) Purchase UMKM Ayra \& Eve products Likert due to needs or desires.

The Influence of Social Media, Product Quality, and Price on Purchasing Decisions on UMKM Ayra \& Eve in Surabaya

Weni Widiasti Ningrum, I Nyoman Sudapet, Hamzah Denny Subagio ${ }^{3}$ 
purchasing decision from the consumer, the product or service will not sell in the market.
2) Buy UMKM Ayra \& Eve products on the basis of information and related sources.

3) Decide to buy UMKM Ayra \& Eve products after selecting other alternatives.

Source: Author (2019)

\section{Data Analysis Techniques}

In this study using multiple linear regression analysis to determine how much influence the independent variable (independent) on the dependent variable (dependent) on changes from each increase or decrease in the independent variable that will affect the dependent variable [14]. Multiple linear regression analysis is used to analyze the influence of the independent variables (social media, product quality, price) on the dependent variable, namely the purchasing decision.

The mathematical formulas of multiple linear regression used in this study are:

$$
\begin{aligned}
& \mathrm{Y}=\mathrm{a}+\mathrm{b} 1 \mathrm{X} 1+\mathrm{b} 2 \mathrm{X} 2+\mathrm{b} 3 \mathrm{X} 3+\mathrm{e} \\
& \text { Description: } \\
& \mathrm{Y}=\text { Purchase Decision } \\
& \mathrm{a}=\text { Constant } \\
& \mathrm{b} 1, \mathrm{~b} 2 \text {, b3 = regression coefficient } \\
& \mathrm{x} 1=\text { Social Media } \\
& \mathrm{x} 2=\text { Product Quality } \\
& \mathrm{x} 3=\text { Price } \\
& \mathrm{e}=\text { error disturbances }
\end{aligned}
$$

\section{Test of Reliability and Validity}

To test the validity of the questionnaire, the researcher conducted a validity test which was used to support the regression analysis. Validity shows the extent to which the accuracy and accuracy of a measuring instrument in performing the function of the measuring instrument (SaiffudinAzwar, 2001). Valid instruments can be used to uncover data from variables that are correctly searched. The minimum requirements that must be agreed to are requirements if $r$ count $>r$ table. 


\section{Correlation Coefficient (R) and Determination Coefficient (R2)}

Correlation coefficient $(\mathrm{R})$ is used to determine the relationship between independent variables $(\mathrm{X})$ to the dependent variable (Y) together. The coefficient of determination (R2) essentially measures how far the model's ability to explain variations in the independent variable.

\section{Hypothesis Testing}

1) The F test is used to determine whether the independent variable has a significant influence or not on the dependent variable.

2) The $t$ test is used to see whether the independent variable depends partially on the dependent variable.

\section{Classic Assumption Test}

1) Multicollinearity Test, Testing this assumption to show the existence of a linear relationship between the independent variables in the regression model and to show the presence or absence of a high degree of colinearity among the independent variables.

2) Heteroscedasticity test, used to test whether in the regression model variance or residual inequality occurs one observation to another observation

3) Normality Test, aims to test whether in the regression model the intruder or residual variable has a normal distribution.

\section{RESEARCH RESULTS AND DISCUSSION}

\section{Reliability Test}

Table 2. Test Result Reliability

\begin{tabular}{|c|c|}
\hline \multicolumn{2}{|c|}{ Reliability Statistics } \\
\hline $\begin{array}{l}\text { Cronbach's } \\
\text { Alpha }\end{array}$ & $\mathrm{N}$ of Items \\
\hline .932 & 16 \\
\hline
\end{tabular}

The data of this study have cronbach's alpha 0.932 and are above 0.60 , so the data of this study can be declared reliable.

\section{Validity Test}

Table 3. Test Result Validity

\begin{tabular}{|c|c|c|c|c|}
\hline No. & Indicator/Variable & Correlation & r Table & Information \\
\hline \multicolumn{5}{|c|}{ Social Media } \\
\hline 1. & $\mathrm{X} 1.1$ & 0,544 & 0,1852 & Valid \\
\hline 2. & $\mathrm{X} 1.2$ & 0,547 & 0,1852 & Valid \\
\hline 3. & $\mathrm{X} 1.3$ & 0,708 & 0,1852 & Valid \\
\hline
\end{tabular}

The Influence of Social Media, Product Quality, and Price on Purchasing Decisions on UMKM Ayra \& Eve in Surabaya

Weni Widiasti Ningrum, I Nyoman Sudapet, Hamzah Denny Subagio ${ }^{3}$ 


\begin{tabular}{ccccc}
\hline 4. & X1.4 & 0,709 & 0,1852 & Valid \\
\hline \multicolumn{1}{c}{ Product Quality } & & & \\
\hline 2. & X2.1 & 0,667 & 0,1852 & Valid \\
\hline 3. & X2.2 & 0,689 & 0,1852 & Valid \\
\hline 4. & X2.3 & 0,672 & 0,1852 & Valid \\
\hline 5. & X2.4 & 0,580 & 0,1852 & Valid \\
\hline 6. & X2.5 & 0,730 & 0,1852 & Valid \\
\hline & X2.6 & 0,707 & 0,1852 & Valid \\
\hline 1. & Price & & & Valid \\
\hline 2. & X4.1 & 0,517 & 0,1852 & Valid \\
\hline 3. & X4.2 & 0,773 & 0,1852 & Valid \\
\hline & X4.3 & 0,664 & 0,1852 & Valid \\
\hline 1. & Purchasing Decision & & 0,1852 & Valid \\
\hline 2. & Y.1 & 0,735 & 0,1852 & Valid \\
\hline 3. & Y.2 & 0,647 & 0,1852 & \\
\hline
\end{tabular}

Source : Processed SPSS Output Data

Validity test shows that all indicators used to measure social media variables (X1), product quality (X2), and price (X3), and purchasing decisions $(\mathrm{Y})$ used in this study have correlation coefficients or rcounts greater than rtable $=0.1852$ (rtable value for $\mathrm{n}=80$ ). So that all these indicators are valid.

\section{Determination Coefficient Test $R$ and adjusted $R$ square}

Table 4. Test Results Determination Coefficient

\begin{tabular}{llllll}
\hline Model Summary & & & & \\
\hline Model & $\mathrm{R}$ & R Square & $\begin{array}{l}\text { Adjusted } \\
\text { Square }\end{array}$ & $\mathrm{R}$ & $\begin{array}{l}\text { Std. Error of the } \\
\text { Estimate }\end{array}$ \\
\hline dimension0 & 1 & $.833^{\mathrm{a}}$ & .693 & .681 & .41841 \\
\hline a. Predictors: (Constant), X3, X1, X2 & & & \\
\hline
\end{tabular}

Source: SPSS output data

Based on the table beside the coefficient value of $\mathrm{R}>0.5$ which is equal to 0.833 . This means that social media variables (X1), product quality (X2), and price (X3), have a significant effect on purchasing decisions (Y).Adjusted R Square results are 0.681 which shows that social media variables (X1), product quality (X2), price (X3), have an effect of $68.1 \%$ on purchasing decisions (Y). And the remaining $31.9 \%$ is influenced by other variables not examined in this study. 


\section{Multiple Regression Linier}

Table 5. Result Multiple Regression Linier

\begin{tabular}{|c|c|c|c|c|c|}
\hline Keterangan & $\mathbf{B}$ & t hitung & t table & Sig & \\
\hline Konstanta & $-0,008$ & & & & \\
\hline Social Media & 0,278 & 3,430 & 1,9917 & & 0,001 \\
\hline Product Quality & 0,553 & 6,003 & 1,9917 & & 0,000 \\
\hline \multirow[t]{9}{*}{ Price } & 0,086 & 1,039 & 1,9917 & & 0,302 \\
\hline & & & $\mathbf{R}$ & 0,833 & \\
\hline & & & Rsquare & 0,693 & \\
\hline & & & $R$ adjusted & 0,681 & \\
\hline & & & F hitung & 0,000 & \\
\hline & & & F tabel & 1,9917 & \\
\hline & & & Sig & 0,500 & \\
\hline & & & Df & 76 & \\
\hline & & & SEE & 41,841 & \\
\hline
\end{tabular}

Source: SPSS output data

Regression equation models that can be written from these results in the form of standard form regression equations are as follows :

$$
\begin{aligned}
& Y=-0,008+0,278 X 1+0,553 X 2+0,086 \mathrm{X} 3 \pm 83,3347 \\
& Y R \max =(-0,008-83,3374)+0,278 \mathrm{X} 1+0,553 \mathrm{X} 2+0,086 \mathrm{X} 3 \\
& Y R \min =(-0,008-83,3374)+0,278 \mathrm{X} 1+0,553 \mathrm{X} 2+0,086 \mathrm{X} 3
\end{aligned}
$$

\section{Hypothesis testing}

\begin{tabular}{|c|c|c|c|c|c|c|}
\hline \multicolumn{7}{|c|}{ ANOVA $^{b}$} \\
\hline \multicolumn{2}{|c|}{ Model } & $\begin{array}{l}\text { Sum of } \\
\text { Squares }\end{array}$ & $d f$ & $\begin{array}{c}\text { Mean } \\
\text { Square }\end{array}$ & $F$ & Sig. \\
\hline \multirow[t]{3}{*}{1} & Regression & 30.080 & 3 & 10.027 & 57.274 & $.000^{\mathrm{a}}$ \\
\hline & Residual & 13.305 & 76 & .175 & & \\
\hline & Total & 43.384 & 79 & & & \\
\hline
\end{tabular}

Test F (Simultaneous)

Table 6. F Result Test (simultan)

\footnotetext{
a. Predictors: (Constant), X3, X1, X2

b. Dependent Variable: $Y$
}

Source: SPSS Output Data

Based on the table above it is known that obtained Fcount $=57,274$ while the Ftable value is obtained at 2.66. Thus F count 46,845> F table 2.72. And a significant value of $0,000<0.05$ so that it can be

The Influence of Social Media, Product Quality, and Price on Purchasing Decisions on UMKM Ayra \& Eve in Surabaya

Weni Widiasti Ningrum, I Nyoman Sudapet, Hamzah Denny Subagio ${ }^{3}$ 
concluded that social media (X1), product quality (X2) and price (X3) simultaneously have a positive and significant effect on purchasing decisions (Y) on UMKM Ayra\&Eve in Surabaya.

\section{Uji t (Partial)}

Table 7. T Result Test (Partial)

\begin{tabular}{|c|c|c|c|c|c|c|}
\hline \multicolumn{7}{|c|}{ Coefficients $^{\mathrm{a}}$} \\
\hline \multicolumn{2}{|c|}{ Model } & \multicolumn{2}{|c|}{ Unstandardized Coefficients } & $\begin{array}{l}\text { Standardized } \\
\text { Coefficients } \\
\text { Beta }\end{array}$ & \multirow{3}{*}{$\begin{array}{l}\mathrm{t} \\
-.034\end{array}$} & \multirow{3}{*}{$\begin{array}{l}\text { Sig. } \\
.973\end{array}$} \\
\hline & & & & & & \\
\hline 1 & (Constant) & -.008 & .220 & & & \\
\hline & $\mathrm{X} 1$ & .278 & .081 & .289 & 3.430 & .001 \\
\hline & $\mathrm{X} 2$ & .553 & .092 & .553 & 6.003 & .000 \\
\hline & $\mathrm{X} 3$ & .086 & .083 & .093 & 1.039 & .302 \\
\hline
\end{tabular}

a. Dependent Variable: $\mathrm{Y}$

Source: SPSS Output Data

Based on the table above it is known that the value of $t$ count $>t$ table of social media variables (X1) is 3,430 , the variable of product quality (X2) is 6,003 and the price variable (X3) is 1,039.

\section{Classic Assumption Test}

\section{1) Multicollinearity Test}

Table 8. Multicollinearity Test Results

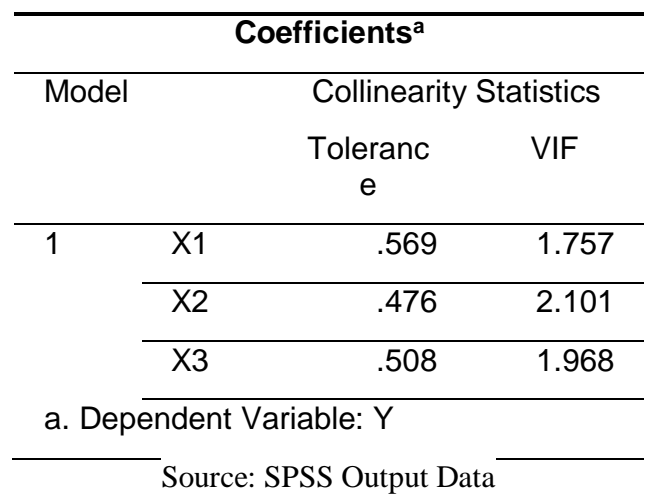

Based on the table above it can be seen that the regression model does not experience multicollinearity. This can be seen in the tolerance value of each independent variable greater than 0.1 . The VIF calculation results also show that the VIF value of each independent variable is less than 10 . So it can be concluded that there is no multicollinearity between independent variables in the regression model 


\section{2) Heteroscedasticity Test}

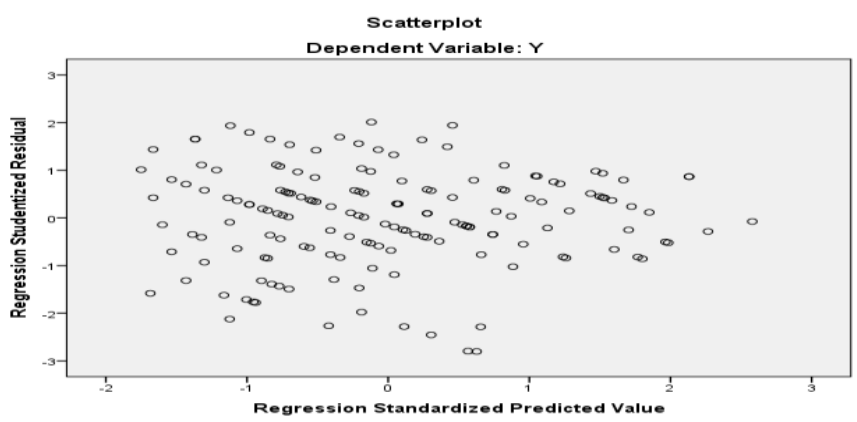

From the Scatterplot graph in the picture above it can be seen that the points spread randomly, both above and below the zero on the $\mathrm{Y}$ axis. It can be concluded that the model in this study

\section{3) Normality test}

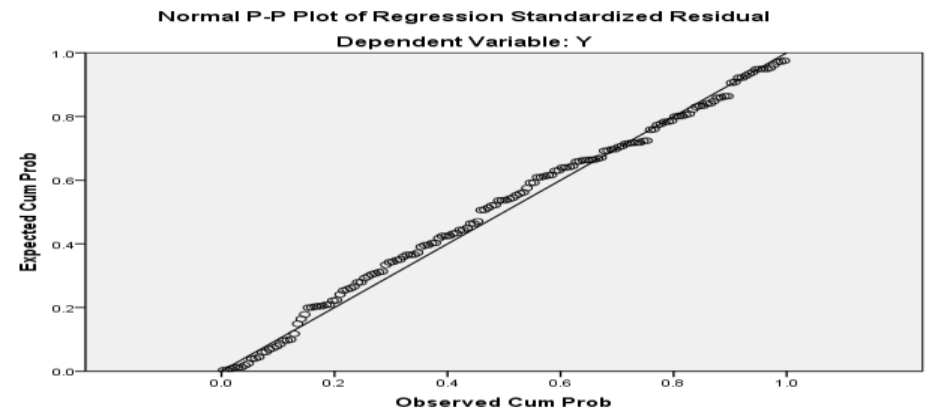

In the picture above it can be seen that the standardized normal probability plot of regression graph shows a normal graph pattern. This can be seen from the points that spread around the diagonal line and the diagonal line from the lower left to the top right. Then it can be concluded that the regression model is feasible because it meets the assumptions of normality.

\section{Testing the Influence of Social Media on Purchasing Decisions}

The test results obtained by $\mathrm{t}$ value calculated for social media variables on purchasing decisions showed the value of tcount $=3.430>$ from ttable 1.991 with a significance of $0.001<0.05$, which means significant. Thus partially social media has a positive and significant effect on purchasing decisions on UMKMAyra\&Eve in Surabaya.

\section{Testing the Influence of Product Quality on Purchasing Decisions}

The test results obtained by t value calculated for product quality variables on purchasing decisions shows the value of tcount $=6.003>$ from ttable 1.991 with a significance of $0.000<0.05$, which means significant. Thus partially product quality has a positive and significant effect on purchasing decisions on UMKM Ayra\&Evein Surabaya.

Testing the Influence of Prices on Purchasing Decisions

The Influence of Social Media, Product Quality, and Price on Purchasing Decisions on UMKM Ayra \& Eve in Surabaya

Weni Widiasti Ningrum, I Nyoman Sudapet, Hamzah Denny Subagio ${ }^{3}$ 
The test results obtained by the value of $t$ count for the price variable on purchasing decisions shows the value of $\mathrm{t}$ count $=1.039$ <from $\mathrm{t}$ table 1.991 with a significance of $0.332>0.05$, which means not significant. Thus partially the price does not have a positive and significant effect on purchasing decisions on UMKM Ayra\&Evein Surabaya. This is because, prices are not a top priority by consumers in the UMKM Ayra\&Eve. Because at the UMKM Ayra\&Eve, the products sold are gifts / gifts for various events / custom gifts (according to customer orders). So that consumers do not really see the price, because what is purchased is a gift / gift to give to others.

\section{CONCLUSION}

Social Media (X1) has a significant influence on Purchasing Decisions (Y). Where the significance value of $\mathrm{X} 1=0.001<0.05$. The decision to purchase MSMEs is influenced by social media which is a marketing tool used. Product Quality (X2) has a significant influence on Purchasing Decisions (Y). Where the significance value of $\mathrm{X} 2=0,000<0,05$. This is because UMKM consumers Ayra\& Eve agree that product quality has a positive effect on purchasing decisions. Price (X3) has no significant effect on Purchasing Decisions (Y). Where the value of $\mathrm{X} 3=0.302>0.05$. This is because consumers do not see the price, because sold are products for gifts that are special gifts (can be ordered). So consumers buy products for others by looking at the product not the price. So the price has no significant effect. Social media variables (X1), product quality (X2) and price (X3) simultaneously have a significant effect on Purchasing Decisions (Y) with significant values smaller than 0.05 , which is 0,000 .

The results of this study indicate that by maintaining social media as a good marketing tool and improving the quality of products that are owned, it will make consumers continue to make purchasing decisions on UMKM Ayra\& Eve in Surabaya. And with cheaper prices for each product, consumers will be increasingly interested in buying, not just to give gifts to others. In addition, this research can be a reference for further research on the same topic and other variables because there may be other variables besides social media, product quality, prices that might influence purchasing decisions. This is because the value of R Square shows that there are other variables that are not studied which can influence purchasing decisions.

\section{REFERENCES}

Assauri, S. (2004). Manajemen Pemasaran. (Edisi II.). Rajawali Press. Jakarta.

Joseph F. Hair. (2014). PLS-SEM: Indeed a Silver Bullet. PLS-SEM: Indeed a Silver Bullet (January 2015), 37-41.

Kotler, P, dan K. (2009). Manajemen Pemasaran. (Edisi 12.). Penerbit Indeks, Jakarta.

kotler, philip \& keller, kevin lane. (2012). marketing management (14th ed.). United State : Pearson.

Kotler, Phillip \& Keller, K. L. (2012). Marketing Management (14 th edit). United State : Pearson.

Kotler dan Armstrong, G. (2008). Dasar-Dasar Pemasaran. (Edisi 11.). Penerbit Indeks, Jakarta.

Kotler, P. (2005). Manajamen Pemasaran, Jilid 1 dan 2. Jakarta: PT. Indeks Kelompok Gramedia.

Lupioadi, R. (2001). Manajemen Pemasaran Jasa. (Edisi 2). Salemba Empat. Jakarta.

Payne, A. . (2007). Pemasaran Jasa (Cetakan Ke). Andi and Pearson Education, Yogyakarta .

Schiffman, L. G. and L. L. K. (2004). Customer Behavior. Prentice Hall Inc. USA.

Simamora, B. (2003). Membongkar Kotak Hitam Konsumen. Gramedia Pustaka Utama.Jakarta.

Sugiyono. (2008). METODE PENELITIAN BISNIS (cetakan 11). Alfabeta, Bandung.

The Influence of Social Media, Product Quality, and Price on Purchasing Decisions on UMKM Ayra \& Eve in Surabaya

Weni Widiasti Ningrum, I Nyoman Sudapet, Hamzah Denny Subagio³ 